\title{
Prognosis factors for dengue shock syndrome in children
}

\author{
Eka Fitri Sari Ningrum* \\ Husada Bunda Hospital, Malang, Indonesia
}

\section{Abstract}

Background: Varied clinical manifestations, complex pathogenesis, and different viral serotypes make it difficult to predict the course of dengue disease. Many studies have been conducted on the prognostic factors for the occurrence of dengue shock syndrome (SSD), but all use the 2017 World Health Organization (WHO) guidelines.

Aim: This study aims to determine the prognostic factors for the occurrence of SSD based on WHO guidelines in 2011.

Method: Retrospective study using medical record data of pediatric patients aged 0 to $<18$ years with a diagnosis of dengue fever dengue (DHF), SSD, and expanded dengue syndrome (EDS) that meet WHO criteria in 2011 at the reputable database from 2017 to December 2020. Independent variables, namely gender, age, nutritional status, secondary dengue infection, leukopenia, abdominal pain, gastrointestinal bleeding, hepatomegaly, and plasma leakage. Shock is the dependent variable. Multivariate analysis using logistic regression analysis.

Results: Subjects who met the study criteria were 145 patients, $52(35.8 \%)$ of whom had SSD. Five of 52 SSD patients went into shock during hospitalization. The bivariate analysis yielded significant factors including, malnutrition, overnutrition and obesity, gastrointestinal bleeding, hemoconcentration, ascites, leukocytes $5,000 \mathrm{~mm} 3$, encephalopathy, enzyme elevation heart, and overload. The results of multivariate analysis showed that hemoconcentration variables and elevated liver enzymes were factors of SSD Prognosis.

Conclusion: Hemoconcentration and elevated liver enzymes are prognostic factors for SSD.

\section{Introduction}

The complex pathogenesis, and Differences in viral serotypes in regions different, makes it difficult for us to predict the course of dengue disease especially in assessing whether the patient will go into shock or shock repeated [1]. The search for prognostic factors feels very important in predicting possible cases that evolve into SSD [2]. Many studies have been carried out in Indonesia or abroad about prognostic factors occurrence of shock in pediatric patients with dengue fever dengue (DHF). All previous research using the World Health Organization guidelines (WHO) 1997 on the management of viral infections dengue [2-13]. SSD mortality rate is $7.81 \%$ and prevalence still high $15.53 \%$ SSD [3] and viral infection classification latest dengue according to WHO guidelines 2011 [14] with the new group of expanded dengue syndrome (EDS) is the reason for doing this research. Expanded dengue syndrome can be associated with shock in dengue $[3,14,15]$.

\section{More Information}

*Address for Correspondence:

Eka Fitri Sari Ningrum, Husada Bunda Hospital, Malang, Indonesia,

Email: amalia1991@uin-malang.ac.id

Submitted: September 27, 2021

Approved: October 14, 2021

Published: October 15, 2021

How to cite this article: Ningrum EFS.

Prognosis factors for dengue shock syndrome in children. J Clin Intensive Care Med. 2021; 6: 033-037.

DOI: 10.29328/journal.jcicm.1001039

Copyright: @ 2021 Ningrum EFS. This is an open access article distributed under the Creative Commons Attribution License, which permits unrestricted use, distribution, and reproduction in any medium, provided the original work is properly cited.

Keywords: SSD; Prognosis; Children

Check for updates

OPEN ACCESS
Disease with dengue infection imperils approximately 20 million individuals each year in tropical and subtropical countries [29]. The mortality rate is around $1 \%-2 \%$. The range of malady signs is wide, extending from asymptomatic or gentle contamination, through shifting degrees of thrombocytopenia and vascular spillage that's ordinary of dengue hemorrhagic fever (DHF), to a serious stun disorder and multiorgan failure [30]. Different organs can be influenced: liver harm, rhabdomyolysis, myocardial misery, and different neurologic and ophthalmologic signs have been reported [30]. The case casualty of extreme dengue in Asian nations is around $0.5 \%-3.5 \%$ [31].

Dengue infections are transmitted to people by contaminated mosquitoes, basically Aedes aegypti and Aedes albopictus [29]. There are four serotypes of the dengue infection: sorts 1, 2, 3, and 4. Even though alluded to as serotypes, these have been recognized as four diverse species having a place in the family Flaviviridae and sort Flavivirus. 
Contamination with the dengue infection incorporates a wide run of appearances. Numerous diseases are asymptomatic. Symptomatic dengue comes about in two characterized syndromes: dengue fever (DF) and DHF/DSS. Whereas DF could be a straightforward, self-limiting febrile ailment, DHF could be an extreme and possibly life-threatening condition. DHF/DSS is characterized by thrombocytopenia, with the resultant hemorrhagic signs; in expansion, there's expanded vascular porousness, coming about in drained intravascular volume and stun. Serious, significant stun is known to happen in extraordinary cases and is related to tall mortality.

Two speculations have been proposed to clarify the pathophysiology of DHF/DSS [32]. Agreeing to one hypothesis, DHF/DSS is caused by more destructive strains of the dengue infection. The other hypothesis proposes that DHF/DSS comes about from irregular and overstated have safe reactions - in specific, the generation of dengue infection cross-reactive antibodies - which increases the disease. In essential disease with the dengue infection, cross-reactive antibodies that need neutralizing action are created. Amid auxiliary disease by a distinctive serotype, the dengue infection and nonneutralizing antibodies shape virus-antibody complexes. The Fc parcel of these antibodies tie to Fc $\gamma$ RI- and Fc $\gamma$ RII-bearing cells, coming about in an expanded number of cells being contaminated by the dengue virus [33]. This wonder is known as an antibody-dependent upgrade and is accepted to play an imperative portion within the pathogenesis of shock [33-36].

Patients with extreme dengue pass on dynamically declining stun and multiorgan disappointment. The precise mechanism of this marvel isn't completely caught on even though it is thought that expanded vascular penetrability happens generally due to the breakdown of vascular endothelial cells actuated by cytokines or chemical mediators [37], as moreover happens in extreme sepsis. It appears that a Th1 reaction happens within the, to begin with, few days of dengue contamination; this afterward switches over to a Th2 reaction, which relates to the improvement of shock [38]. TNF- $\alpha$, interleukin (IL)-2, IL-6, and IFN- $\gamma$ levels are most elevated within the, begin with 3 days of ailment, while IL-10, IL-5, and IL-4 tend to seem later [38]. IL-2 and IFN- $\gamma$ are Th1type cytokines, whereas IL-5 and IL-4 are Th2-type cytokines. Dengue virus-infected monocytes and endothelial cells have been appeared to deliver numerous cytokines, counting TNF- $\alpha[39,40]$.

Within the nearness of upgrading antibodies, monocytes tainted with dengue infection create TNF- $\alpha$. TNF- $\alpha$ has been appeared to initiate plasma spillage in vitro [42]. Basophils and pole cells contaminated with dengue infection create IL- 1 and IL-6, whereas IFN- $\gamma$, IL-2, and TNF- $\alpha$ are moreover delivered by virus-specific $\mathrm{T}$ lymphocytes upon activation [41,43]. Lymphocytes tainted with the dengue infection create IFN- $\alpha$ and IFN- $\gamma$ [44], IFN- $\alpha$ levels are higher in patients with DHF, although there's no contrast in its levels in several grades of DHF [46]. IFN- $\gamma$ levels are not distinctive in patients with DF and DHF [45].
The variables which put patients at higher hazard of creating dengue stun are not clearly distinguished, however. DHF/DSS is more likely to happen in infants [46], and the elderly [46-48]. Dengue disease too shows up to be more serious in females [49]. Serious dengue is more likely to happen in patients with a constant ailment such as diabetes mellitus or asthma [50,51], even though lack of healthy sustenance inclines to numerous irresistible infections it does not show up to extend the probability of extreme dengue [52]. The serotype of the contaminating infection may impact the seriousness of dengue; DEN-1 disease, taken after by DEN-2 disease, has been detailed to be associated with more awful outcomes [53]. There are a few that prove that hereditary helplessness (ethnic variation [54], HLA typing [55], etc.) may play a part in the improvement of dengue stun, but this has not been examined completely.

The purpose of this study was to determine the factors prognostic factors in dengue virus infection potential for dengue shock syndrome based on 2011 WHO guidelines on the management of dengue virus infection.

\section{Method}

This study is a prognostic study that is a retrospective cohort. The prognostic factors studied, namely gender, age, nutritional status, dengue infection secondary, leukopenia, abdominal pain, bleeding gastrointestinal tract, hepatomegaly, and leakage plasma. This research was conducted in a reputable database, data taken from medical records. The subjects of this study were children aged $0-<18$ years with a diagnosis of DHF, SSD, and EDS that were treated from January 1, 2017, until 31 December 2020. The number of samples is calculated using the rule formula of thumb and the results obtained 145 subjects. Taking the sample is done by consecutive sampling. Variable dependent is dengue shock syndrome. Independent variables are gender, age, nutritional status, dengue secondary infection, leukopenia, abdominal pain, bleeding gastrointestinal tract, hepatomegaly, and plasma leakage. The data were processed with the SPSS version 14.0 program. Statistical analysis using bivariate analysis, analysis multivariate with logistic regression, and curve analysis ROC.

\section{Results}

Medical record data are taken from January 1, 2017, until December 2020. There are 400 medical data records of subjects with dengue virus infection. One hundred and nineteen incomplete medical records. One hundred and thirtysix subjects were excluded because 100 were diagnosed with DD, 36 hematology-oncology, and infection. Subjects who met the inclusion criteria were 145 subjects, 44 (30.3\%) of them had EDS (Chart 1).

The characteristic of the patients based on gender are mention in Chart 2. 
Medical record data are taken from January 1, 2017, until December 31, 2020. There are 400 data medical records of subjects with dengue virus infection. One hundred and nineteen incomplete medical records. One hundred and thirtysix subjects were excluded because 100 were diagnosed with DD, 36 hematology-oncology, and infection. Subjects who met the inclusion criteria were 145 subjects, 44 (30.3\%) of them had EDS.

The bivariate analysis resulted in several factors significant prognostic $(p<0.05)$, namely nutrition poor-less (malnutrition) to good nutrition, nutrition over-obesity to good nutrition, urinary tract bleeding digestion, hemoconcentration, ascites, leukocytes $5000 / \mu \mathrm{L}$, encephalopathy, elevated liver enzymes, and overload. The multivariate analysis used is analysis logistic regression. The results of the multivariate analysis listed in Table 2 obtained variables with $p<0.05$, namely the hemoconcentration equation variables, EDS, and increase in liver enzymes. The analysis of the ROC results produces the equation hemoconcentration and elevated liver enzymes. The discriminatory ability of the equation in differentiating those predicted to experience dengue shock syndrome is good (area under the receiver operating characteristic curve [AUC] 0.818 with $p<0.01$ and $95 \%$ CI: $0.750-0.886$ ).

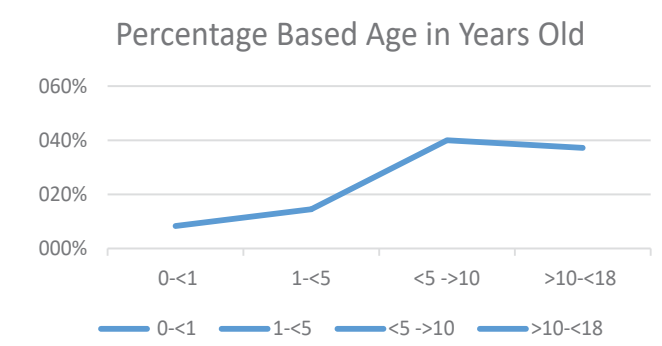

Chart 1: Clinical Manifestation Based Age in Years Old.

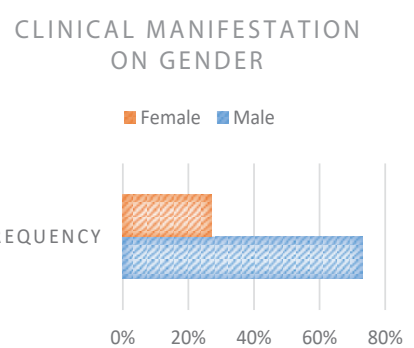

Chart 2: Clinical Manifestation Based Gender.

Table 1: Laboratory characteristics of research subjects.

\begin{tabular}{|c|c|}
\hline Laboratory characteristics of research subjects & Total, $\boldsymbol{n}(\%)$ \\
\hline Secondary dengue infection $(n=109)$ & $52(47.7 \%)$ \\
\hline Hemoconcentration (increased hematocrit $20 \%)$ & $100(69 \%)$ \\
\hline Leukocytes $<5000 \mathrm{~L}$ & $60(41.4 \%)$ \\
\hline Thrombocytopenia $<100,000 \mathrm{~L}$ & $125(86.2 \%)$ \\
\hline
\end{tabular}

Table 2: Multivariate analysis of SSD prognostic factors.

\begin{tabular}{|c|c|c|}
\hline Table 2: Multivariate analysis of SSD prognostic factors. \\
\hline Variable & $\boldsymbol{p}$ & OR \\
\hline Hemoconcentration & 0.001 & 40,035 \\
\hline Increased liver enzymes & 0.001 & 21,827 \\
\hline
\end{tabular}

\section{Discussion}

The SSD subjects in this study were mostly aged 5 years is $71.1 \%$. This can be caused due to [21] more microvascular structures and permeability is easier to increase [11]. Female subjects with more SSD, ie $48.4 \%$ [56]. The immune response may be more sensitive to cytokine secretion in girls [6]. Kids women may have vascular permeability high intrinsic [22]. Huy's [4] study reported relationship between female gender and risk shock is not clearly understood. DHF children with malnutrition and overnutrition have a greater risk of developing shock or EDS $[4,11,23]$. The activity of the immune system develops by good nutrition, overnutrition, and obesity, so that cause increased viral proliferation and more severe disease manifestations $[1,11,24]$. Obesity can exacerbate dengue infection due to increased production of white adipose tissue which causes increased production of mediators.

This results in progressive plasma leakage that ends at risk of higher SSD [12]. Study Trang, [25] reports there is no statistically significant relationship between DHF and SSD children with malnourished patients, overnutrition, and obesity. Abdominal pain experienced by many (63.4\%) subjects SSDs. Huy's study shows clear evidence of a relationship between abdominal pain and dengue shock [4]. Abdominal pain is a marker of splanchnic blood flow reduced to hypoxia during pre and intra shock [6] and signs of severe gastrointestinal bleeding histopathological [8]. This study found hepatomegaly in a few (21.1\%) subjects' SSD.

Huy's study reports hepatomegaly is strongly associated with SSD. Hepatomegaly may be related to strains and viral serotypes [1]. Degree of hepatomegaly or liver pain no correlation with abnormal liver function. Hepatomegaly is a normal response to infection dengue, but it is more related to DHF and SSD compared to DD [26]. SGOT increase is most possibly caused by monocyte damage. Aminotransferase value generally reaches a maximum around the 9th sick day and decreases gradually to normal within 2 weeks. Severe dengue hemorrhagic fever (SSD) is associated with acute and severe liver damage, especially due to massive direct infection of hepatocytes and Kupffer cells with minimal cytokine response [19].

Fewer SSD subjects (19.2\%) experienced Gastrointestinal bleeding in the form of hematemesis (15.4\%) and melena (3.8\%). Bleeding will exacerbate the loss of plasma volume due to leakage, thereby accelerating the occurrence of shock [1]. Bleeding can be caused by platelet dysfunction, vasculopathy, and/or coagulopathy [6]. Hematemesis and melena are a manifestation of heavy bleeding that is frequently found [26]. Hemoconcentration $20 \%$ experienced by $98.1 \%$ subjects SSDs. An increase in hematocrit by $20 \%$ proves increased vascular permeability, plasma leakage, and is correlated with disease severity $[1,5,12]$.

Ascites and pleural effusion on SSD respectively a number 
5.8\% and 15.4\%. Ascites, pleural effusion, and hemoconcentration are risk factors or predictor means dengue shock. $[4,7,21,26,27]$ Secondary dengue infection experienced $40.4 \%$ of subjects SSDs. This may be due to the role of antibody-dependent enhancement in the pathogenesis of SSD [4]. Cells $\mathrm{T}$ is activated during secondary infection due to the interaction of infected monocytes resulting in the release of a cascade of cytokines such as interferon-gamma, interleukin 2 , and tumor necrosis factor-alpha. This process will induce plasma leakage and lead to shock [21].

SSD subjects who have leukopenia it's only $25 \%$. Bivariate analysis showed a significant difference between leukopenia and shock, but as a protective factor against shock. Leukopenia until mild leukocytosis is always seen near the end of the febrile phase. When body temperature drops, Many patients have leukopenia due to suppression of Bone marrow [7]. Leukopenia reaches its peak just before the fever goes down and it's back to normal 2-3 days after defervescence [28]. The number of DHF subjects who experienced EDS was 44 of 145 (30.3\%) subjects. Types of EDS in DHF subjects the most, namely an increase in liver enzymes (14.5\%), overload (12.4\%), and encephalopathy (9.6\%). Subject SSDs experiencing EDS number 34 out of 47 . (72.3\%) subjects SSD. The most common types of EDS in the SSD subject group, namely elevated liver enzymes (40.4\%), overload (38.3\%), and encephalopathy (23.4\%).

\section{Conclusion}

Hemoconcentration (hematocrit increase 20\%) and elevated liver enzymes are significant prognosis factors in the occurrence of shock dengue based on multivariate analysis.

\section{References}

1. Raihan, Hadinegoro SR, Tumbelaka AR. Prognostic factors shock in dengue hemorrhagic fever. Sari Pediatrics. 2010; 12: 47-52.

2. Pawitan JA. Dengue virus infection: predictors for severe dengue. Acta Med Indonesia. 2011; 43: 129-135.

PubMed: https://pubmed.ncbi.nlm.nih.gov/21785176/

3. Hadinegoro SR, Moedjito I, Chairulfatah A, editors. Guidelines for the diagnosis and management of dengue virus infection in child. Jakarta: IDAI Publishing Agency. 2014; 1-6.

4. Huy NT, Van Giang T, Thuy DH, Kikuchi M, Hien TT, et al. Factors associated with dengue shock syndrome: a systematic review and meta-analysis. Plos Negl Trop. 2013; 7: 1-13.

PubMed: https://pubmed.ncbi.nlm.nih.gov/24086778/

5. Tantracheewathorn T, Tantracheewathorn S. Risk factors of dengue shock syndrome in children. J Med Assoc Thai. 2007; 90: 272-277. PubMed: https://pubmed.ncbi.nlm.nih.gov/17375631/

6. Pongpan S, Wisitwong A, Tawichasri C, Patumanond J. Prognostic indicators for dengue infection severity. Int J Clin Pediatr. 2013; 2: 12-18.

7. Gupta V, Yadav TP, Pandey RM, Singh A, Gupta M, et al. Risk factors of dengue shock syndrome in children. J Trop Pediatr. 2011; 57: 451-456. PubMed: https://pubmed.ncbi.nlm.nih.gov/21367851/

8. Kan EF, Slim TH. Factors associated with shock in children with dengue hemorrhagic fever. Indonesian Pediatrics. 2004; 44: 171-175.
9. Dewi R, Tumbelaka AR, Syarif DR. Clinical features of dengue hemorrhagic fever and risk factors of shock event. Pediatrics Indonesia. 2006; 46: 144-148.

10. Pham TB, Nguyen TH, Vu TQ, Nguyen TL, Malvy D. Predictive factors of dengue shock syndrome in children hospital no. 1 Ho-chi-Minh City, Vietnam. Bull Soc Pathol Exot. 2007; 100: 43-47.

PubMed: https://pubmed.ncbi.nlm.nih.gov/17402695/

11. Junia J, Garna H, Setiabudi D. Clinical risk factors for dengue shock syndrome in children. Paediatr Indonesia. 2007; 47: 7-11.

12. Widiyati MMT, Laksanawati IS, Prawirohartono EP. Obesity as a risk factor for dengue shock syndrome in children. Pediatrician Indonesia. 2013; 53: 187-192.

13. Mayetti. The relationship between clinical and laboratory features as risk factors for shock in dengue hemorrhagic fever. Sari Pediatrics. 2010; 11: 367-373.

14. World Health Organization. Comprehensive guidelines for prevention and control of dengue and dengue hemorrhagic fever: revised and expanded edition. New Delhi: South East Asian Region Office-World Health Organization. 2011; 17.

15. Kadam DB, Salvi S, Chandanwale A. Expanded dengue. J Assoc Physician India. 2016; 64: 59-63.

PubMed: https://pubmed.ncbi.nlm.nih.gov/27759344/

16. Pediatric nutritional care. Departmental clinical practice guide RSCM pediatrics. Jakarta. RSCM; 2015; 306-309.

17. Boamah L, Balistreri WF. Manifestations of liver disease. In: Behrman RE, Kliegman RM, Arvin AM, editors. Nelson textbook of pediatrics. 18th edition. Philadelphia: WB Saunders. 2007; 1662.

18. Matondang CS, Wahidiyat I, Sastroasmoro S. Abdomen. In: Matondang CS, Wahidiyat I, Sastroasmoro S, editor. Physical diagnosis in children. 2nd Edition. Jakarta: Sagung Seto. 2000; 103.

19. Soedarmo SS, Garna H, Hadinegoro S, Satari H. Virus infection dengue. In: Soedarmo SS, Garna H, Hadinegoro S, Satari Hi, editor. Textbook of tropical infections and pediatrics. Edition 2nd. Jakarta: IDAI Publishing Agency. 2008. pp.155-81.

20. Dengue virus infection. Science department clinical practice guide RSCM child health. Jakarta: RSCM. 2015; 167-182.

21. Pothapregada S, Kamalakannan B, Thulisingham M. Risk factors for shock in children with dengue fever. Indian J Crit Care Med. 2015; 19 : 661-664.

PubMed: https://www.ncbi.nlm.nih.gov/pmc/articles/PMC4687175/

22. Phubhakdi CB, Hemunkorn M, Thisyakorn Usa, Thisyakorn C. Risk factors influencing severity in pediatric dengue infections. Asian Biomedicine. 2008; 2: 409-413.

23. Kalayanarooj $\mathrm{S}$, Nimmanitya $\mathrm{S}$. Is dengue severity related to nutritional status? Southeast Asian J Trop Med Public Health. 2005; 36: 378-384. PubMed: https://pubmed.ncbi.nlm.nih.gov/15916044/

24. Halstead SB. Dengue fever/dengue hemorrhagic fever. In: Behrman RE, Kliegman RM, Arvin AM, editors. Nelson textbook of pediatrics. 18th edition. Philadelphia: WB Saunders. 2007; 1005-1007.

25. Trang NTH, Long NP, Hue TTM, Hung LP, Trung TD. Association between nutritional status and dengue infection: a systematic review and meta-analysis. BMC Infect Dis. 2016; 16: 172-183. PubMed: https://pubmed.ncbi.nlm.nih.gov/27097934/

26. Yulianto A, Laksono IS, Juffrie M. Prognostic factors of degree severity of dengue infection. Sari Pediatrics. 2016; 18: 198-203.

27. Ramachandran S, Geral A, Kamall M, Geral R, Roy MP. Changing trends in clinicopathological parameters in dengue with evaluation of predictors of poor outcome in children. Int J Contemp Pediatr. 2016; 3: $1411-1415$

28. Risniati Y, Tarigan LH, Emiliana Tjitra E. Leukopenia as predictors of 
dengue shock syndrome in children with dengue hemorrhagic fever in RSPI. Prof. dr. Sulianti Saroso. Health Res Dev Media. 2011; 21: 96-102.

29. 2nd Edition. World Health Organization; 19977. Dengue haemorrhagic fever: diagnosis, treatment, prevention and control.

30. Halstead SB. Dengue. Lancet. 2007; 370: 1644-1652. PubMed: https://pubmed.ncbi.nlm.nih.gov/17993365/

31. Halstead SB. Is there an inapparent dengue explosion? Lancet. 1999 353: 1100-1101.

PubMed: https://pubmed.ncbi.nlm.nih.gov/10199378/

32. Kurane I. Dengue hemorrhagic fever with special emphasis on immunopathogenesis. Comp Immunol Microbiol Infect Dis. 2007; 30 329-340.

PubMed: https://pubmed.ncbi.nlm.nih.gov/17645944/

33. Littaua R, Kurane I, Ennis FA. Human IgG Fc receptor II mediates antibody-dependent enhancement of dengue virus infection. J Immunol. 1990; 144: 3183-3186.

PubMed: https://pubmed.ncbi.nlm.nih.gov/2139079/

34. Mady BJ, Erbe DV, Kurane I, Fanger MW, Ennis FA. Antibodydependent enhancement of dengue virus infection mediated by bispecific antibodies against cell surface molecules other than $\mathrm{Fc}$ gamma receptors. Antibody-dependent enhancement of dengue virus infection mediated by bispecific antibodies against cell surface molecules other than Fc gamma receptors. 1991; 147: 3139-3144. PubMed: https://pubmed.ncbi.nlm.nih.gov/1680925/

35. Halstead SB, Venkateshan CN, Gentry MK, Larsen LK. Heterogeneity of infection enhancement of dengue 2 strains by monoclonal antibodies. J Immunol. 1984; 132: 1529-1532.

PubMed: https://pubmed.ncbi.nlm.nih.gov/6607288/

36. Morens DM. Antibody-dependent enhancement of infection and the pathogenesis of viral disease. Clin Infect Dis. 1994; 19: 500-512. PubMed: https://pubmed.ncbi.nlm.nih.gov/7811870/

37. Basu A, Chaturvedi UC. Vascular endothelium: the battlefield of dengue viruses. FEMS Immunol Med Microbiol. 2008; 53: 287-299. PubMed: https://pubmed.ncbi.nIm.nih.gov/18522648/

38. Chaturvedi UC, Agarwal R, Elbishbishi EA, Mustafa AS. Cytokine cascade in dengue hemorrhagic fever: implications for pathogenesis. FEMS Immunol Med Microbiol. 2000; 28: 183-188. PubMed: https://pubmed.ncbi.nlm.nih.gov/10865168/

39. Green S, Rothman A. Immunopathological mechanisms in dengue and dengue hemorrhagic fever. Curr Opin Infect Dis. 2006; 19: 429-436. PubMed: https://pubmed.ncbi.nlm.nih.gov/16940865/

40. Anderson R, Wang S, Osiowy C, Issekutz AC. Activation of endothelial cells via antibody-enhanced dengue virus infection of peripheral blood monocytes. J Virol. 1997; 71: 4226-4232.

PubMed: https://pubmed.ncbi.nlm.nih.gov/9151809/

41. Green S, Rothman A. Immunopathological mechanisms in dengue and dengue hemorrhagic fever. Curr Opin Infect Dis. 2006; 19: 429-36. PubMed: https://pubmed.ncbi.nlm.nih.gov/16940865/

42. King CA, Anderson R, Marshall JS. Dengue virus selectively induces human mast cell chemokine production. J Virol. 2002; 76: 8408-8419. PubMed: https://pubmed.ncbi.nlm.nih.gov/12134044/

43. Kurane I, Meager A, Ennis FA. Induction of interferon alpha and gamma from human lymphocytes by dengue virus-infected cells. J Gen Virol. 1986; 67: 1653-1661.

PubMed: https://pubmed.ncbi.nlm.nih.gov/3116147/

44. Kurane I, Innis BL, Nimmannitya S, Nisalak A, Meager A, et al. High levels of interferon alpha in the sera of children with dengue virus infection. Am J Trop Med Hyg. 1993; 48: 222-229.

PubMed: https://pubmed.ncbi.nlm.nih.gov/8447527/

45. Vitarana $\mathrm{T}$, de Silva $\mathrm{H}$, Withana N, Gunasekera C. Elevated tumour necrosis factor in dengue fever and dengue haemorrhagic fever. Ceylon Med J. 1991; 36: 63-65.

PubMed: https://pubmed.ncbi.nlm.nih.gov/1913986/

46. Guzmán MG, Kouri G, Bravo J, Valdes L, Vazquez S, Halstead SB, et al. Effect of age on outcome of secondary dengue 2 infections. Int $J$ Infect Dis. 2002; 6: 118-124.

PubMed: https://pubmed.ncbi.nlm.nih.gov/12121599/

47. GuzmánMG,KouríG.Dengue:anupdate.LancetInfectDis.2002;2:33-42. PubMed: https://pubmed.ncbi.nlm.nih.gov/11892494/

48. Malavige GN, Velathanthiri VG, Wijewickrama ES, Fernando S, Jayaratne SD, et al. Patterns of disease among adults hospitalized with dengue infections. QJM. 2006; 99: 299-305.

PubMed: https://pubmed.ncbi.nlm.nih.gov/16603571/

49. Kabra SK, Jain Y, Pandey RM, Madhulika, Singhal T, et al. Dengue haemorrhagic fever in children in the 1996 Delhi epidemic. Trans R Soc Trop Med Hyg. 1999; 93: 294-298.

PubMed: https://pubmed.ncbi.nlm.nih.gov/10492762/

50. Bravo JR, Guzmán MG, Kouri GP. Why dengue haemorrhagic fever in Cuba? 1. Individual risk factors for dengue haemorrhagic fever/dengue shock syndrome (DHF/DSS) Trans R Soc Trop Med Hyg. 1987; 81: 816-820.

PubMed: https://pubmed.ncbi.nlm.nih.gov/3450004/

51. Cunha RV, Schatzmayr HG, Miagostovich MP, Barbosa AM, Paiva FG, et al. Dengue epidemic in the State of Rio Grande do Norte, Brazil, in 1997. Trans R Soc Trop Med Hyg. 1999; 93: 247-249.

PubMed: https://pubmed.ncbi.nlm.nih.gov/10492750/

52. Thisyakorn U, Nimmannitya S. Nutritional status of children with dengue hemorrhagic fever. Clin Infect Dis. 1993; 16: 295-297. PubMed: https://pubmed.ncbi.nlm.nih.gov/8443312/

53. Guzmán MG, Kouri GP, Bravo J, Soler M, Vazquez S, et al. Dengue hemorrhagic fever in Cuba, 1981: a retrospective seroepidemiologic study. Am J Trop Med Hyg. 1990; 42: 179-184.

PubMed: https://pubmed.ncbi.nlm.nih.gov/2316788/

54. Halstead SB, Streit TG, Lafontant JG, Putvatana R, Russell K, et al. Haiti: absence of dengue hemorrhagic fever despite hyperendemic dengue virus transmission. Am J Trop Med Hyg. 2001; 65: 180-183. PubMed: https://pubmed.ncbi.nlm.nih.gov/11561700/

55. Loke H, Bethell DB, Phuong CX, Dung M, Schneider J, et al. Strong HLA class I-restricted T cell responses in dengue hemorrhagic fever: a double-edged sword? J Infect Dis. 2001; 184: 1369-1373. PubMed: https://pubmed.ncbi.nlm.nih.gov/11709777/

56. Diana M. Korelasi antara trombositopenia dengan hemokonsentrasi sebai faktor predisposisi terjadinya syok pada pasien demam berdarah dengue dewasa di RSUP Dr.Kariadi Semarang. [Artikel Hasil Karya Tulis IImiah]. Semarang: Program Pendidikan Sarjana Kedokteran Fakultas Kedokteran Universitas Diponegoro; 2007. 